\title{
Electroencephalographic and behavioral convulsant effects of hydrobromide and hydrochloride salts of bupropion in conscious rodents
}

\author{
David C Henshall' \\ Nick Dürmüller ${ }^{2}$ \\ H Steve White ${ }^{3}$ \\ Robert Williams ${ }^{4}$ \\ Paul Moser ${ }^{2}$ \\ Mark Dunleavy' \\ Peter H Silverstone ${ }^{5}$ \\ 'Department of Physiology \\ and Medical Physics, Royal College \\ of Surgeons in Ireland, Dublin, Ireland; \\ ${ }^{2}$ Porsolt and Partners Pharmacology, \\ Le Genest-Saint-Isle, France; \\ ${ }^{3}$ NeuroAdjuvants, Inc., Salt Lake City, \\ UT, USA; ${ }^{4}$ Biovail Technologies, Ltd., \\ Dublin, Ireland; ${ }^{5}$ Biovail Corporation, \\ Mississauga, ON, Canada
}

\begin{abstract}
A novel bromide salt of the antidepressant bupropion (bupropion $\mathrm{HBr}$ ) has recently been developed and approved for use in the United States. Given previous use of bromides to treat seizures, and that the existing chloride salt of bupropion $(\mathrm{HCl})$ can cause seizures, it is important to determine if the $\mathrm{HBr}$ salt may be less likely to cause seizures than the $\mathrm{HCl}$ salt. In the present animal studies this was evaluated by means of quantified electroencephalogram (EEG), observation, and the rotarod test in mice and rats. Both bupropion salts were tested at increasing equimolar doses administered intraperitoneally. The results in mice showed that bupropion $\mathrm{HCl}$ $125 \mathrm{mg} / \mathrm{kg}$ induced a significantly higher ten-fold increase in the mean number of cortical EEG seizures compared to bupropion $\operatorname{HBr}(7.50 \pm 2.56$ vs $0.75 \pm 0.96 ; p=0.045)$, but neither drug caused any brain injuries. In rats bupropion $\mathrm{HBr} 100 \mathrm{mg} / \mathrm{kg}$ induced single EEG seizure activity in the cortical and hippocampal (depth) electrodes and in significantly $(p<0.05)$ fewer rats (44\%) compared to bupropion $\mathrm{HCl}$, which induced 1 to 4 convulsions per rat in all rats $(100 \%)$ dosed. The total duration of cortical seizures in bupropion HCl-treated rats was significantly longer than the corresponding values obtained in bupropion $\mathrm{HBr}$-treated rats (424.6 seconds vs 124.5 seconds respectively, $\mathrm{p}<0.05$ ). Bupropion $\mathrm{HCl}$ consistently induced more severe convulsions at each dose level compared to bupropion $\mathrm{HBr}$. Both treatments demonstrated a similar dose-dependent impairment of rotarod performance in mice. In conclusion, these findings suggest that bupropion $\mathrm{HBr}$ may have a significantly lower potential to induce seizures in mice and rats, particularly at higher doses, compared to bupropion $\mathrm{HCl}$. Determination of this potential clinical advantage will require human studies. If confirmed by such studies, it is likely that this potential beneficial clinical benefit would be due to the presence of the bromide salt given the long history of the use of bromide to treat seizure disorders.
\end{abstract}

Keywords: bupropion hydrobromide, bupropion hydrochloride, EEG, seizures, mice, rats, motor impairment

\section{Introduction}

Bupropion hydrochloride $(\mathrm{HCl})$, a widely used antidepressant, is associated with a dose-dependent risk of seizures when given at therapeutic doses or following overdose in humans, ${ }^{1-6}$ and in animals. ${ }^{7,8}$ The precise mechanism of bupropion-induced seizures remains unknown. Recently, Biovail (Biovail Laboratories International SRL, St. Michael, Barbados) has developed a new extended-release tablet formulation of bupropion hydrobromide $(\mathrm{HBr})$ for once-daily administration. The administration of bupropion $\mathrm{HBr}$ to steady-state levels was safe and well tolerated for up to five weeks in healthy nonsmoking adult volunteers. ${ }^{9}$ The bromide salt was chosen for stability reasons. However, once developed there arose the possibility that this formulation had a reduced seizure risk compared to bupropion $\mathrm{HCl}$. This is because high-dose bromide is associated with treatment of seizures. Bromides were first introduced in the treatment of seizures in 1857 by Sir Charles Locock ${ }^{10,11}$ and gained wide usage until
Correspondence: Peter Silverstone Departments of Neuroscience and Psychiatry, University of Alberta, 8440-I I 2 Street, Edmonton,

Canada,T6R 2AI

Tel +I 7804076576

Fax +l 7804076672

Email peter.silverstone@ualberta.ca 
the introduction of phenobarbital in 1912. When phenytoin was introduced in 1937, it heralded the demise of bromides as antiepileptic drugs in the modern age of antiepileptics. ${ }^{12}$ Although the mechanism of action of bromide as an antiseizure agent is not known, developing a hydrobromide salt of bupropion may therefore potentially reduce the seizure risk associated with the use of bupropion.

The objectives of these studies were to: (i) assess the electroencephalographic and behavioral convulsant, and central nervous system effects of bupropion $\mathrm{HBr}$ in comparison to the effects of equimolar doses of bupropion $\mathrm{HCl}$ in conscious mice and rats, and (ii) show a difference, if any, in the sensitivity of the rodents to the two salts of bupropion.

\section{Materials and methods}

\section{Mice electroencephalogram study}

The objectives of this study were to: (a) determine the comparative cortical electroencephalogram (EEG) proconvulsant effects of equimolar doses of bupropion $\mathrm{HCl}$ and bupropion $\mathrm{HBr}$ in mice, and (b) determine if the bupropion-induced seizures were associated with any histopathological brain injury, and if so, determine any differences between the two salts in the magnitude of the injury.

The study was conducted at the In vivo Neuroscience Laboratory, Department of Physiology and Medical Physics, Royal College of Surgeons in Ireland, Dublin, Ireland. All experimental and operational procedures were performed in accordance with the current standard operating procedures of the Biomedical Research Facility at the Royal College of Surgeons in Ireland and the research study was undertaken under the remit of current Research Ethics Committee approval for the study of seizure effects in mouse models (REC 098).

\section{Animals}

Thirty (30) female CD-1 mice (Charles River laboratories, Margate, Kent, UK) weighing 25-29 g were housed in groups of five to six per cage in standard polypropylene cages for mice with stainless steel lids in the Biomedical Research Facility. They were acclimatized for a minimum period of four days with standard laboratory rodent processed sawdust used as bedding material in the cages in an environmentally controlled animal room (temperature $22 \pm 3{ }^{\circ} \mathrm{C}$; relative humidity $50 \% \pm 20 \%$ ) with a 12 -hour light/dark cycle. Each cage was identified using cage cards with information on the researcher/principal investigator, study number, cage number, animal number, number of animals, species, strain, sex, signature of technician and start date. After allocation to groups, each animal was uniquely identified by markings on the dorsal surface of the tail. The cages were changed weekly or as necessary. Throughout the study, all animals had free access ad libitum to feed and mains water via plastic water bottles. Prior to the initiation of treatment, animals were randomly assigned to doses as follows: Group 1: $150 \mathrm{mg} / \mathrm{kg}$ by intraperitoneal (IP) injection-bupropion $\mathrm{HCl}$ ( $\mathrm{n}=4$ mice), and bupropion $\mathrm{HBr}(\mathrm{n}=4$ mice); Group 2: $135 \mathrm{mg} / \mathrm{kg}$ IP-bupropion $\mathrm{HCl}$ ( $\mathrm{n}=2 \mathrm{mice}$ ), and bupropion $\mathrm{HBr}(\mathrm{n}=2$ mice); Group 3: $125 \mathrm{mg} / \mathrm{kg}$ IP-bupropion $\mathrm{HCl}$ ( $\mathrm{n}=4$ mice), and bupropion $\mathrm{HBr}(\mathrm{n}=4$ mice); Group 4: $115 \mathrm{mg} / \mathrm{kg} \mathrm{IP}$-bupropion $\mathrm{HCl}$ ( $\mathrm{n}=2 \mathrm{mice}$ ), and bupropion $\mathrm{HBr}(\mathrm{n}=2 \mathrm{mice})$; and Group 5: $100 \mathrm{mg} / \mathrm{kg} \mathrm{IP}$-bupropion $\mathrm{HCl}(\mathrm{n}=2$ mice $)$, and bupropion $\mathrm{HBr}(\mathrm{n}=2$ mice $)$. A clinical examination was performed on each animal by a trained technician at the start of acclimatization and on study day -1 . Animals in poor health or those considered unsuitable for use in the study were not assigned to treatment groups and unassigned animals were released from the study.

\section{Drugs}

Bupropion $\mathrm{HCl}$ was obtained from Biovail Technologies (Ireland) Ltd. (Manufacturer: Erregierre Sp.A., San Paolo d'Argon [BG], Italy), in white powder form, with lot number GP0409070, expiry date of September 2006, and was stored in a cool $\left(15-25^{\circ} \mathrm{C}\right)$, dry place protected from light. Bupropion $\mathrm{HBr}$ was obtained from Biovail Technologies (Ireland) Ltd. (Manufacturer: Chemi SPA, Patrica [FR], Italy), in white powder form, with lot number E00287, expiry date of November 2006 , and was stored in a cool $\left(15-25^{\circ} \mathrm{C}\right)$, dry place protected from light. The diluent was $0.9 \%$ sodium chloride solution (IV infusion BP) obtained from Baxter Healthcare Ltd. (Norfolk, England, UK), with lot number 05L22BS, expiry date of November 2007 , and was stored at $\leq 25^{\circ} \mathrm{C}$.

The dose formulations of both bupropion $\mathrm{HCl}$ and bupropion $\mathrm{HBr}$ were prepared on each day of administration. The appropriate amount of bupropion $\mathrm{HCl}$ or bupropion $\mathrm{HBr}$ was weighed into a suitable container and added to $0.9 \%$ sodium chloride solution to achieve the desired concentration of each compound. Bupropion $\mathrm{HBr}$ was adjusted to be equimolar to bupropion $\mathrm{HCl}$. The mixture was shaken for $5 \mathrm{~min}$ followed by sonication for $5 \mathrm{~min}$, if required, until dissolved. On each day of treatment, bupropion $\mathrm{HCl}$ was administered by IP injection in a dose volume of $10 \mathrm{ml} / \mathrm{kg}$ and dose concentration of either $10,11.5,12.5,13.5$, or $15 \mathrm{mg} / \mathrm{ml}$ for the $100,115,125,135$, and $150 \mathrm{mg} / \mathrm{kg}$ doses, respectively. Similarly, on each day of treatment, bupropion $\mathrm{HBr}$ was administered by IP injection in a dose volume of $10 \mathrm{ml} / \mathrm{kg}$ and dose concentration of either $11.6,13.34,14.5,15.7$, or 
$17.4 \mathrm{mg} / \mathrm{ml}$ for the $100,115,125,135$, and $150 \mathrm{mg} / \mathrm{kg}$ doses, respectively. The actual dose administered was based on the most recent body weight of each animal.

\section{Study procedure}

All animals were weighed and their body weights were recorded on study day -1 and study day 0 . General health observations were performed on all animals twice daily, at least five hours apart, except at weekends when they were performed once daily from the start of acclimatization up to and including the final day of the study.

\section{Electrode placement}

After the acclimation period, habituated mice were anesthetized with isoflurane, then placed in a stereotaxic frame and maintained normothermic $\left(36-37^{\circ} \mathrm{C}\right)$ by means of a feedback-controlled mouse-designed homeothermic blanket (Harvard Apparatus, Holliston, MA, USA). Under isoflurane anesthesia, a midline skin incision was made over the skull and the skull was exposed. Three partial craniectomies were performed, one overlying each temporal lobe and a third overlying the frontal cortex. Mouse-sized cranial EEG E363/20 electrode with mounting screw and socket (Plastics One Inc., Roanoke, VA, USA) were affixed at each point. The electrode assembly was fixed to the skull with dental cement, anesthesia was then discontinued and the animal was placed in the recording chamber for 30-60 min after recovery. The electrodes were connected to a multichannel 363 Connector Cable System (Plastics One Inc.) with SL6C 6 channel swivel commutator (Plastics One Inc.). Baseline EEG recordings were then commenced using a Grass model Comet Portable 40-channel EEG Recording and Review System with twin digital EEG in tandem with continuous digital video (Astro-Med Inc., West Warwick, RI, USA).

\section{Experimental protocol}

After baseline video-EEG recordings for $10 \mathrm{~min}$, mice were injected with single doses of bupropion $\mathrm{HCl}$ or bupropion $\mathrm{HBr} 100,115,125,135$, or $150 \mathrm{mg} / \mathrm{kg}$ IP using a $1 \mathrm{ml}$ disposable syringe and 26 gauge needle. Mice were run in parallel so that a $\mathrm{HCl}$ mouse was injected within minutes of an $\mathrm{HBr}$ mouse and recordings were made simultaneously. VideoEEG was recorded for a period of one hour. Thereafter, mice were returned to cages and then euthanized at 24 hours and the brains harvested for histopathology.

\section{EEG analysis}

All EEG were scored visually. The number of occurrences and the duration of four patterns of EEG were calculated for each mouse over the one hour recording period, using the following EEG classification ${ }^{13}$ described previously: Type 1 - low frequency and amplitude resting/baseline EEG; Type II - high frequency, low amplitude ictal fast EEG; Type III - low frequency, high amplitude EEG; and Type IV - high frequency, high amplitude EEG. EEG seizure activity was defined as Type IV polyspike high frequency $(>1 \mathrm{~Hz})$ EEG activity that were $>2 \mathrm{X}$ the amplitude at baseline (high amplitude).

Behavioral scoring for the occurrence, number and duration of seizures was periodically undertaken.

\section{Histopathology study}

To investigate whether the recorded EEG seizure activity induced by bupropion $\mathrm{HCl}$ and bupropion $\mathrm{HBr}$ caused any brain injury, the tissue sections of harvested mice brains were stained with two different markers of neuronal loss/damage: terminal deoxynucleotidyl dUTP nick end labeling (TUNEL) which identifies apoptotic and necrotic neurons in situ, ${ }^{14,15}$ and Fluoro-Jade B staining which shows degenerating neuronal cells. ${ }^{16-18}$ In addition, NeuN, a specific marker for neurons, ${ }^{19}$ was used to immunostain viable neurons.

\section{Immunohistochemistry and DNA fragmentation analysis} Since a distinction in EEG seizure activity was only seen at the $125 \mathrm{mg} / \mathrm{kg}$ dose, the brains from mice treated with this dose of each salt of bupropion were extracted whole 24 hours following administration of the study drug and was flash frozen at $-20{ }^{\circ} \mathrm{C}$ to $-30{ }^{\circ} \mathrm{C}$. The brains were stored temporarily at $-80{ }^{\circ} \mathrm{C}$. Brains from bupropion $\mathrm{HCl}$-treated mice ( $\mathrm{n}=3$ : Bup9, Bup11 and Bup13) and bupropion $\mathrm{HBr}$-treated mice ( $\mathrm{n}=3$ : Bup10, Bup12, and Bup14) were sectioned at a thickness of $12 \mu \mathrm{m}$ on a Leica model cryostat (Leica Microsystems GmbH, Wetzlar, Germany), each at the level of the substantia nigra (bregma), dorsal hippocampus and caudate-putamen (striatum). The sections were incubated overnight at room temperature in a 1:500 dilution of mouse anti-neuronal nuclear protein (NeuN; Chemicon International, Inc., Temecula, CA, USA) to label neurons. On the second day, sections were stained for cell death using terminal deoxynucleotidyl dUTP nick end-labeling (TUNEL; Roche Molecular Biochemicals, Indianapolis, IN, USA), a marker of double-stranded DNA breaks and apoptosis. Sections were then mounted in medium containing 4', 6-diamidino-2-phenylindole ([DAPI]; Vector Laboratories, Inc., Burlingame, CA, USA) to visualize nuclei. TUNEL were examined using a Nikon 2000s epifluorescence microscope with a $40 \mathrm{X}$ oil immersion lens under excitation/emission 
wavelengths of 330-380/420 nm (blue), 472/520 nm (green) and 540-580/600-660 nm (red). A total of ten X40 fields were selected across each brain area, five from each side of the brain, and a mean count obtained. A cumulative total count for each side was taken and then the mean count of the two sides was determined. A positive control material for permanent seizure damage within the hippocampus was provided by injecting kainic acid into the amygdala of C57Bl/6 mice, which induces status epilepticus and a lesion to hippocampal CA3 neurons. Briefly, mice received intraamygdala injection of $0.3 \mu \mathrm{KA}$ (Sigma-Aldrich, St. Louis, MO, USA) and sections cut as described above at 24 hours as previously described. ${ }^{20,21}$

Sections of the brains of mice with bupropion $\mathrm{HCl}$ - and bupropion $\mathrm{HBr}$-induced seizures were also stained with Fluoro-Jade B by using the method described by Schmued and Hopkins. ${ }^{17,18}$ The sections were then analyzed as described for the TUNEL-stained sections above.

\section{Rat electroencephalogram study}

The EEG study in mice, utilizing only cortical electrodes, did not detect any seizure activity at the 100, 115, 135, and $150 \mathrm{mg} / \mathrm{kg}$ doses of either salt despite the profound behavioral convulsions observed at the $150 \mathrm{mg} / \mathrm{kg}$ dose. Therefore, EEG studies in rats were conducted with both cortical and stereotaxically implanted hippocampal (depth) electrodes to evaluate the effects of IP bupropion $\mathrm{HBr}$ compared to equimolar doses of bupropion $\mathrm{HCl}$ on EEG activity.

The EEG studies in rats were conducted at Porsolt and Partners Pharmacology Research Laboratory, Le GenestSaint-Isle, France. All experiments were performed in accordance with French legislation concerning the protection of laboratory animals and in accordance with a currently valid license for experiments on vertebrate animals, issued by the French Ministry for Agriculture and Fisheries to the study director.

\section{Animals}

Male Rj: Wistar (Han) rats (Elevage Janvier, Le Genest-SaintIsle, France), weighing 280-324 g at the time of electrode implantation were housed in groups of five animals maximum, in macrolon cages $(44 \times 28 \times 19 \mathrm{~cm})$ containing wood litter (Litalabo - SPPS, Argenteuil, France). The animals were housed in an environmentally controlled vivarium with ambient temperature of $21 \pm 3{ }^{\circ} \mathrm{C}$, relative humidity of 30\%-80\%, and a 12-hour light (7:00 to 19:00) and dark cycle. The animals had free access ad libitum to food (Code 113 - SAFE, Augy, France) and tap water. After electrode implantation, the animals were kept individually in macrolon cages $(30 \times 18 \times 19 \mathrm{~cm})$ in a separate room for implanted animals under the same environmental conditions as before and had free access to food and tap water except during the test sessions. Animals were identified by marking the connector fixed on the animal's head with an indelible pen. Ten animals were randomly assigned to each treatment. Animals assigned to bupropion $\mathrm{HCl}$ received $10,30,60$, and $100 \mathrm{mg} / \mathrm{kg}$ by IP injection while animals assigned to bupropion $\mathrm{HBr}$ received equimolar doses to the bupropion $\mathrm{HCl}$ doses, also intraperitoneally. Rats were sacrificed at the end of the experiments humanely by anesthetic overdose.

Dosage selection in this study was based on the results of a preliminary dose-finding study that evaluated the effects of equimolar doses of bupropion $\mathrm{HCl}$ and bupropion $\mathrm{HBr}$ in the range $30-150 \mathrm{mg} / \mathrm{kg}$ IP on the EEG trace in conscious male Wistar rats. The results of that study revealed that both salts of bupropion induced behavioral convulsions and simultaneous EEG seizure activity at doses greater than $70 \mathrm{mg} / \mathrm{kg}$.

\section{Drugs}

Bupropion $\mathrm{HCl}$ and bupropion $\mathrm{HBr}$ were obtained from Biovail Technologies (Ireland) Ltd, each in white powder form with batch numbers GP0409070 and RM0662, respectively. Vehicle was physiological saline (Laboratoire Aguettant, Lyon, France) and the substances were dissolved in physiological saline and prepared freshly on each day of experimentation. All substances were stored in a dry, dark, controlled access area and maintained at a controlled ambient temperature of $20 \pm 3{ }^{\circ} \mathrm{C}$. The vehicle solutions were stored at $4{ }^{\circ} \mathrm{C}$. The substances were administered by IP injection in a dose volume of $5 \mathrm{ml} / \mathrm{kg}$ body weight. The doses of bupropion $\mathrm{HCl}$ are expressed in $\mathrm{mg} / \mathrm{kg}$ of salt and the doses of bupropion $\mathrm{HBr}$ are expressed in $\mathrm{mg} / \mathrm{kg}$ bupropion $\mathrm{HCl}$ molar equivalent $($ correction factor $=1.16)$.

\section{Study procedure}

EEG monitoring in the rat

The effects of the $\mathrm{HCl}$ and $\mathrm{HBr}$ salts of bupropion on the electrical activity in the cortex and hippocampus after IP administration were evaluated by EEG trace monitoring in the conscious rat according to the method described by Dürmüller and colleagues. ${ }^{22}$

\section{EEG electrode implantation}

Electrode implantation surgery was carried out under aseptic conditions. Rats were anesthetized with sodium pentobarbital $60 \mathrm{mg} / \mathrm{kg}$ IP, plus supplementary doses of $5-10 \mathrm{mg} / \mathrm{kg}$ to 
maintain anesthesia. The rats were then implanted with two surface EEG electrodes, consisting of miniature titanium screws placed bilaterally over the frontal-parietal cortex, and two depth electrodes, consisting of twisted platinum-iridium wires placed stereotaxically into the hippocampus CA3 area (Paxinos and Watson coordinates interaural: AP $+5.0 \mathrm{~mm}$, $\mathrm{L} \pm 2.5 \mathrm{~mm}, \mathrm{~V}+7.0 \mathrm{~mm}) .{ }^{23}$ An additional screw placed over the right occipital cortex served as a ground electrode. The electrodes were connected to small plugs and the whole assembly was secured to the skull with dental acrylate. Following surgery, implanted animals were kept in individual macrolon cages $(30 \times 18 \times 19 \mathrm{~cm})$ and were allowed at least 10 days to recover. A total of 27 rats were implanted with EEG electrodes.

\section{EEG recording and testing procedure}

The animals were placed in rectangular Plexiglas cubicles $(30 \times 10 \times 25 \mathrm{~cm})$ mounted on treadmills for the EEG recording. Five recording units were run in parallel. A turning commutator was attached above the centre of each cubicle, about $30 \mathrm{~cm}$ above walking level. On one side, it was connected via an electrically shielded multicore cable to the animal and on the other side to the signal conditioning system (Coulbourn Model V75-01; Coulbourn Instruments, Allentown, PA, USA). The system filters were set for all channels to $1 \mathrm{~Hz}$ and $150 \mathrm{~Hz}$ for the high pass and low pass filters, respectively. The amplification levels were kept between 1,000 and 10,000. The EEG signals were acquired and processed on a personal computer (PC) installed with a 16 channel analog-to-digital data acquisition card that was integrated into a local network (Ethernet) which also included a PC for the data analysis, and a compact disk (CD) writer for data storage.

Before beginning the testing procedure, the rats were habituated in an one-hour training session connected to the recording cable and treadmill which activates the animals to walk and ensure a heightened level of vigilance. ${ }^{22} \mathrm{~A}$ few minutes before launching the first recording, the animals were transferred from the holding to the testing room, connected to the recording cable, and placed into the recording cubicle. The EEG signals were briefly inspected for their quality and the amplification levels were adjusted as necessary. The animals were then given a one-hour recording session without any treatment (baseline control) and with the treadmill intermittently turned on (walking speed: $1.8 \mathrm{~m} / \mathrm{min}$ ) and off at intervals of 10 minutes. Immediately after the end of the baseline control recording, animals were administered IP bupropion $\mathrm{HCl}$ or bupropion $\mathrm{HBr}$ and recorded for another two-hour session. Twenty-three hours after the injection, the animals were given an one-hour recording session under the same experimental conditions as the day before. Then the same recording procedure as on the previous day was repeated until all the doses were tested. The same animal was always run on the same treadmill, connected to the same unit of the signal conditioning system, and the treadmills were always operated with the same recording cables. The EEG signal acquisition and the visual off-line analysis were performed using the IOX2 and ECG_auto softwares (both from EMKA Technologies, Paris, France), respectively.

\section{Behavioral observations}

Animals were observed for one hour before IP injection of treatment (baseline) and for two hours post-treatment for any abnormal behaviors, the occurrence and types of seizures and the number of animals that had seizures. Behavioral observations were recorded as the presence or absence of hypersensitivity/stereotypical behaviors, head twitches, rearing, facial clonus, forelimb clonus, and wholebody clonus. Post hoc, seizure severity was classified according to the method of Racine $^{23}$ as follows: Class I - Facial clonus; Class II - Head nodding; Class III - Forelimb clonus; Class IV - Rearing; Class V - Rearing and falling accompanied by wholebody clonic seizures.

\section{Assessment of relative behavioral proconvulsant activity in mice}

The objective of this study was to compare the behavioral proconvulsant properties of bupropion $\mathrm{HCl}$ and bupropion $\mathrm{HBr}$ in mice. The study was conducted at Charles River Laboratories BioLabs Europe, Ballina, Ireland. The study plan was approved by the Ethics Committee of Charles River Laboratories BioLabs Europe.

\section{Animals}

Sixty $(n=60)$ healthy female CD-1 mice (Charles River Laboratories, Kent, UK) weighing 17.7 to $21.9 \mathrm{~g}$ on study day 0 were housed in groups of 20 during acclimatization and in groups of 5 per cage during the test period. The animals were housed in polypropylene cages measuring approximately $55 \times 34 \times 20 \mathrm{~cm}$ with stainless steel lids and autoclaved dust-free processed sawdust as bedding in an environmentally controlled animal room (temperature 20-23 ${ }^{\circ} \mathrm{C}$; relative humidity $48 \%-69 \%$ ) with artificial lighting and a 12-hour light/dark cycle throughout the duration of the study. All animals were acclimatized to their cages and to the light/dark cycle for at least seven days before the start of the study. In addition, all animals were fed Harlan Teklad 
rat and mouse nonirradiated diet (Harlan Teklad, Blackthorn, UK) and provided water ad libitum via plastic water bottles throughout the study. Animals were randomly assigned to six treatment groups of 10 mice per group on study day -1 , to receive study treatment as follows: three bupropion $\mathrm{HCl}$ single-dose groups of 100,125 , and $150 \mathrm{mg} / \mathrm{kg}$, and three bupropion $\mathrm{HBr}$ single-dose groups of the molar equivalent doses (to bupropion $\mathrm{HCl}$ doses) of 100,125 , and $150 \mathrm{mg} / \mathrm{kg}$. The equimolar doses of bupropion $\mathrm{HCl}$ and bupropion $\mathrm{HBr}$ $100-150 \mathrm{mg} / \mathrm{kg}$ selected for this study were based on the results of a dosage range-finding study conducted previously in the same strain of mice at the same facility. ${ }^{24}$

\section{Drugs}

Both bupropion $\mathrm{HCl}$ and bupropion $\mathrm{HBr}$ were obtained from Biovail Technologies (Ireland) Ltd., Dublin, Ireland, each in white powder form (batch numbers and source: GP0409070, and Erregierre Sp.A., San Paolo d'Argon (BG), Italy; and E00287, and Chemi SPA, Patrica (FR), Italy). The diluent was $0.9 \%$ sodium chloride intravenous infusion BP (batch number 05L22BS; Baxter Healthcare Ltd, Norfolk, England). The dose formulations of bupropion $\mathrm{HCl}$ and bupropion $\mathrm{HBr}$ were prepared in the same manner, with the 100 and $125 \mathrm{mg} /$ $\mathrm{kg}$ dose formulations prepared on study day -1 and that of the $150 \mathrm{mg} / \mathrm{kg}$ dose on study day 0 . The appropriate amount of bupropion $\mathrm{HCl}$ or bupropion $\mathrm{HBr}$ was weighed and dissolved in an appropriate amount of $0.9 \% \mathrm{NaCl}$ and then shaken for 5 min until it dissolved. Prepared test substances were stored at between $20-21^{\circ} \mathrm{C}$. On each study day, the single doses of test substances were administered by IP injection in a dose volume of $10 \mathrm{ml} / \mathrm{kg}$ and dose concentrations of $10,12.5$, and $15 \mathrm{mg} / \mathrm{ml}$ for the 100,125 , and $150 \mathrm{mg} / \mathrm{kg}$ doses of bupropion $\mathrm{HCl}$, and in a dose volume of $10 \mathrm{ml} / \mathrm{kg}$ and dose concentrations of $11.6,14.5$, and $17.4 \mathrm{mg} / \mathrm{ml}$ for the 100,125 , and $150 \mathrm{mg} / \mathrm{kg}$ equimolar doses of bupropion $\mathrm{HBr}$. The actual dose administered was based on the body weight of each animal on study days 0 (100 and $125 \mathrm{mg} / \mathrm{kg})$ and 1 (150 mg/kg).

\section{Study procedure}

All animals had a clinical examination on the day of arrival at the study facility to confirm their suitability for the study and also, on study day -1 . After the acclimatization period, on the day prior to the start of or the start day of study treatment (study day 0 for 100 and $125 \mathrm{mg} / \mathrm{kg}$ and day 1 for $150 \mathrm{mg} / \mathrm{kg}$ ), all animals were weighed and the individual body weights were used for dose volume calculation. Treatment was then administered by IP injection and each group of animals was observed continuously for at least two hours post-treatment.
Details of the number of mice with behavioral convulsions, the number of convulsions, the time of onset of the convulsions, the duration of each convulsion, and the intensity of each convulsion were noted. The intensity of each convulsion was graded using Charles River Laboratories, Inc.'s grading system of either mild: head and tail slightly extended and little jerking; or moderate: head and tail fully extended and some jerking; or severe: head and tail fully extended and strong jerking. Post hoc, the duration of each convulsion was classified as short, medium or long. Short convulsions lasted 0-10 sec, medium convulsions lasted 11-30 sec, and long convulsions lasted $\geq 31 \mathrm{sec}$.

\section{Assessment of behavioral convulsant activity}

The primary outcome variable was the percentage $(\%)$ of mice that had behavioral convulsions. This was the number of animals with behavioral convulsions (mild, moderate, or severe) divided by the total number of animals in each group multiplied by 100 . In addition, the $\mathrm{CD}_{50}$ or convulsive dose ${ }_{50}$, the convulsive dose required to induce convulsions in $50 \%$ of mice, were calculated for the dose-response curves for bupropion $\mathrm{HCl}$ treatment and bupropion $\mathrm{HBr}$ treatment. The secondary outcome variables were the mean number of behavioral convulsions per mouse and the intensity of convulsions.

\section{Behavioral impairment in mice}

The acute behavioral toxicity of bupropion $\mathrm{HBr}$ was evaluated in comparison to that of equimolar doses of bupropion $\mathrm{HCl}$ following IP administration in the rotarod test in mice. The study was conducted at the University of Utah. All mice were housed, fed, and handled in a manner consistent with the recommendations in the National Research Council Publication, "Guide for the Care and Use of Laboratory Animals." No insecticides capable of altering hepatic drug metabolism enzymes were used in the animal facilities. All animals were euthanized in accordance with the Institute of Laboratory Resources policies on the humane care of laboratory animals following the completion of the test. Male albino CF1 mice (Charles River Laboratories, Inc., Wilmington, MA) weighing 25-30 g, were allowed free access to both food (Prolab RMH 3000; PMI Nutrition International, Inc., St. Louis, MO) and water except when they were removed from their cages for the experimental procedure. The test substances were administered IP in a volume of $0.01 \mathrm{ml} / 10 \mathrm{~g}$ body weight in $0.9 \%$ sodium chloride.

\section{Determination of the median toxic dose}

Minimal motor impairment was defined in mice by the standardized rotarod test first described by Dunham and Miya. ${ }^{25}$ 
Inability of a mouse to maintain its equilibrium for a 1-min trial period in each of three trials when placed on a 1-inch knurled rod rotating at $6 \mathrm{rpm}$ was used as an indication of such impairment. All quantitative in vivo toxicity studies were conducted at the previously determined time-to-peak pharmacodynamic effect (TPE). The effect of various doses of the $\mathrm{HCl}$ and $\mathrm{HBr}$ salt of bupropion on rotarod impairment was then quantified in groups of eight mice until at least two points were established between the limits of $0 \%$ and $100 \%$ rotarod toxicity. Doses of bupropion $\mathrm{HCl}$ administered IP were 50, 60, 75, and $100 \mathrm{mg} / \mathrm{kg}$. The corresponding equimolar doses of bupropion $\mathrm{HBr}$ administered IP (corrected for molecular weight) were $75,85,100$, and $150 \mathrm{mg} / \mathrm{kg}$.

\section{Data management and statistical analysis} Mice EEG study

Data are presented as mean $\pm \mathrm{SD}$. The number and duration (in seconds) of EEG seizures in mice were compared between the two bupropion salts using unpaired Student's $t$-test.

\section{Histopathology study}

The mean TUNEL counts of the combined counts from the two sides of the brain sections from bupropion HCl-treated mice were compared to the corresponding mean values obtained for the brain sections from the bupropion $\mathrm{HBr}-$ treated mice and by brain region using the Student's t-test.

\section{Rat EEG study}

The EEG signal was digitized at a sampling rate of $500 \mathrm{~Hz} /$ recording-channel and the data was stored in raw data files. The analysis was performed off-line by visual inspection of the traces. The cortical and hippocampal traces were displayed individually for each rat on the computer screen at a time resolution of $10 \mathrm{sec} /$ window and searched for pathologic activity. Representative samples of pathologic signals were saved in pdf-format files. The EEG irregularities found upon visual off-line inspection were reported descriptively. In addition, the EEG abnormalities were categorized as those occurring at baseline (one hour before IP injection of treatment) and those occurring during the two-hour posttreatment period. Spike trains or spike-and-wave activity clearly exceeding baseline amplitudes and lasting at least one second were defined as seizure activity. Furthermore, the duration of any seizure activity was noted and classified as either short seizure activity defined as seizure activity up to four seconds in duration, or long seizure activity defined as seizure activity between four and 60 seconds. The number of animals with EEG seizure activity and the mean duration of first seizures were compared between the treatments using the Chi-square and unpaired Student's t-tests.

\section{Assessment of relative behavioral convulsant} activity in mice

Data was summarized and presented in tables by treatment groups for the primary outcome variable, the percent (\%) of convulsing mice, and the secondary outcome variables, the mean convulsions per mouse in each treatment group, and the intensity of convulsions. The $\mathrm{CD}_{50}$ values were calculated using the PROBIT procedure in $\mathrm{SAS}^{\circledR}$ version 9.1 (SAS Institute., Cary, NC, USA). The 95\% confidence limits for $\mathrm{CD}_{50}$ were calculated according to the method of Litchfield and Wilcoxon. ${ }^{26}$ The pooled data from the two studies ( 13 mice per dose per treatment; total $=39$ animals per treatment) were used to calculate the $\mathrm{CD}_{50}$ for each treatment. The Cochran-Mantel-Haenszel test was used to detect if the pattern of the intensity (severity) of convulsions changes between the two treatments while adjusting for dose. p-values of $\leq 0.05$ were considered statistically significant.

\section{Behavioral impairment in mice}

The molar dose of each salt required to produce rotarod impairment in $50 \%$ of animals (ie, the $\mathrm{TD}_{50}$ ), the $95 \%$ confidence interval, the slope of the regression line, and the standard error of the mean (SEM) of the slope was calculated by a computer program based on the method described by Finney. ${ }^{27}$

All data are expressed as mean \pm SD or mean \pm SEM, and for all statistical analyses, a p-value of less than 0.05 was considered statistically significant.

\section{Results \\ Mice EEG study}

\section{Behavioral observations}

The $150 \mathrm{mg} / \mathrm{kg}$ dose either salt of bupropion triggered strong seizure-like behavior within 5 min of injection. This was most pronounced during the early recording period (first 15-20 min) but episodic events continued through the one hour of recording. In general, observations suggested behavioral signs of seizure-activity diminished first in $\mathrm{HCl}-$ treated mice.

\section{Mice EEG findings}

Following the IP injection of $150 \mathrm{mg} / \mathrm{kg}$ of both salts in mice ( $n=4$ per salt), within the first five minutes after administration of salts brief (2-3 s) bursts of seizure-like EEG were detected in three of four $\mathrm{HCl}$-treated and two of four 
HBr-treated mice that coincided with the onset of seizure-like behavior in the mice administered each of the salts. No other EEG seizure activity was detected in any of the four pairs of mice with either salt of bupropion following the brief bursts despite ongoing profound behavioral seizures/convulsions.

However, at the $125 \mathrm{mg} / \mathrm{kg}$ dose ( $\mathrm{n}=4$ mice per salt), following injection of both salts, there was some significant EEG seizure activity recorded in 3 pairs of mice with more seizure bursts in the bupropion $\mathrm{HCl}$-administered animals. Both the mean number and duration of recorded EEG seizure activity were about 10 times more following the administration of IP bupropion $\mathrm{HCl} 125 \mathrm{mg} / \mathrm{kg}$ compared to the equimolar dose of bupropion $\mathrm{HBr}$, however, only the mean number of EEG seizures was statistically significantly different (bupropion $\mathrm{HCl}-7.5 \pm 5.3$; bupropion $\mathrm{HBr}-0.8 \pm 1.0$; $\mathrm{p}=0.045$ ) between the two salts (Table 1). No electrographic seizure activity was detected in either mouse with both salts in the fourth pair of mice tested at this dose.

No EEG seizure activity (Type IV seizure bursts) of any significance were detected in any mouse with either bupropion salt following the administration of $100 \mathrm{mg} / \mathrm{kg}$ ( $\mathrm{n}=2$ per salt), $115 \mathrm{mg} / \mathrm{kg}(\mathrm{n}=2$ per salt), or $135 \mathrm{mg} / \mathrm{kg}$ $(n=2$ per salt $)$.

\section{Mice histopathology findings}

Overall, there were either no TUNEL-positive cells in the brain sections of bupropion-treated mice or the mean counts were very low (less than 1) in the sections where they were present. The mean \pm SD TUNEL counts in the bupropion HCl-treated mice brain were $0.3 \pm 0.3,0.7 \pm 0.3$ and 0.0 for the hippocampal, caudate-putamen and substantia nigra sections, respectively. Similarly, the mean \pm SD TUNEL counts in the bupropion $\mathrm{HBr}$-treated mice brain were $0.3 \pm 0.6$, $0.2 \pm 0.3$, and 0.0 for the hippocampal, caudate-putamen and substantia nigra sections, respectively. There were no significant differences between the mean TUNEL counts from the corresponding sections of the brains treated with either salt of bupropion. The few TUNEL-positive cells, where present, likely represent spontaneous/naturally occurring cell death. Essentially no cell death and hence, histopathological injury occurred in the brains of mice killed 24 hours after seizures induced by the administration of $125 \mathrm{mg} / \mathrm{kg}$ IP of bupropion $\mathrm{HCl}$ (Figure 1-E, K and Q) or bupropion $\mathrm{HBr}$ (Figure 1-H, N and T) compared to the control section from the CA3 area of the hippocampus of a mouse with kainic acid-induced seizures that showed TUNEL-positive cells (Figure 1-B).

Also, the Fluoro-Jade B-stained sections from all three regions of the brains of mice with bupropion $\mathrm{HCl}$ - (Figure 1-F, $\mathrm{L}$ and $\mathrm{R}$ ) and bupropion $\mathrm{HBr}$-induced (Figure 1-I, $\mathrm{O}$ and $\mathrm{U}$ ) seizures did not reveal any Fluoro-Jade B-positive neurons compared to the control section from the hippocampus of a mouse with kainic acid-induced seizures that showed Fluoro-Jade B-positive neurons (Figure 1-C). The absence of Fluoro-Jade B-positive neurons in the sections indicates that there were no degenerating neurons and confirms the findings of TUNEL staining.

Immunostaining for neuron-specific antigen ( NeuN immunostaining) of sections from the $\mathrm{HCl} / \mathrm{HBr}$ treated mice confirmed the normal appearance of morphology within neuronal populations in each brain region examined. No NeuN stained cells displayed signs of degeneration in mice treated at $125 \mathrm{mg} / \mathrm{kg}$ IP of bupropion $\mathrm{HCl}$ (Figure 1-D, $\mathrm{J}$ and $\mathrm{P}$ ) or bupropion $\mathrm{HBr}$ (Figure $1-\mathrm{G}$, and $\mathrm{S}$ ). These contrast with the findings in the control section of the hippocampus of a mouse with kainic acid-induced seizures where only a proportion of the cells were stained red (NeuN immunostaining), with the absence of red staining in the CA3 pyramidal neuron subfield of the ipsilateral hippocampus (Figure 1-A) indicating the absence of immunoreactivity probably from degradation of the NeuN antigen because the neurons were at the late stages of the degenerative process

Table I Number and total duration of EEG seizures following intraperitoneal injection of bupropion hydrochloride $125 \mathrm{mg} / \mathrm{kg}$ and equimolar bupropion hydrbromide in mice

\begin{tabular}{|c|c|c|c|c|}
\hline \multirow[t]{2}{*}{ Mice pairs $(n=4)$} & \multicolumn{2}{|c|}{ Number of EEG seizures } & \multicolumn{2}{|c|}{ Duration of EEG seizures (seconds) } \\
\hline & Bupropion $\mathrm{HCl}$ & Bupropion $\mathrm{HBr}$ & Bupropion $\mathrm{HCl}$ & Bupropion $\mathrm{HBr}$ \\
\hline First & 12 & 2 & 290 & 30 \\
\hline Second & 8 & 1 & 130 & 25 \\
\hline Third & 10 & 0 & 115 & 0 \\
\hline Fourth & 0 & 0 & 0 & 0 \\
\hline Mean \pm SD & $7.5 \pm 5.3$ & $* 0.8 \pm 1.0$ & $133.8 \pm 119.3$ & $13.8 \pm 16.0$ \\
\hline
\end{tabular}

Notes: ${ }^{\mathrm{p}} \mathrm{p}=0.045$ compared to corresponding mean for bupropion $\mathrm{HCl}$ by unpaired Student's t-test.

Abbreviations: EEG, electroencephalogram; $\mathrm{HCl}$, hydrochloride; $\mathrm{HBr}$, hydrobromide; $\mathrm{SD}$, standard deviation. 


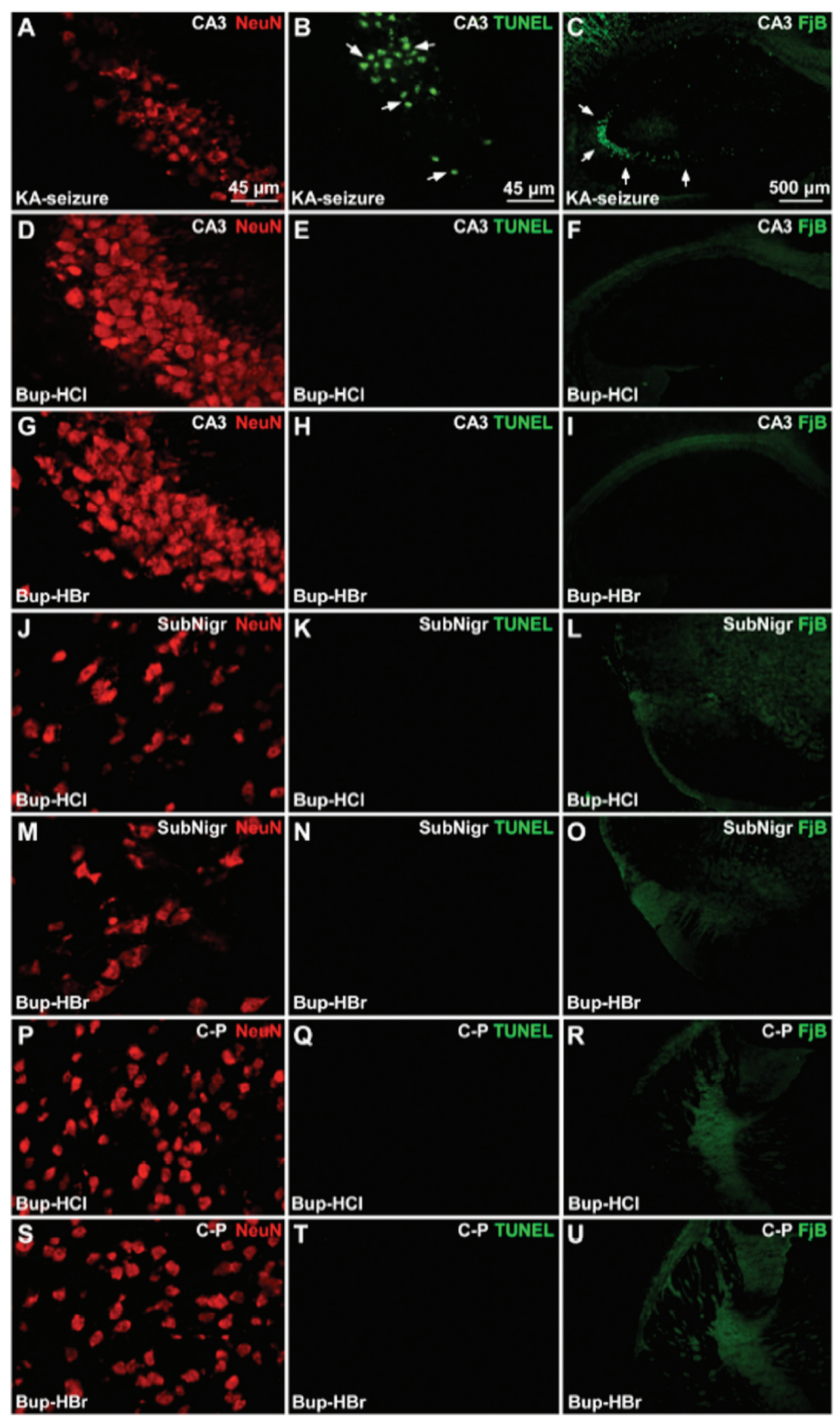

Figure I Representative 40X lens images of NeuN (red),TUNEL (green) and Fluoro-Jade B (green) staining of hippocampal sections of control mice with kainic acid-induced (KA-seizure) seizures (A, B, C, respectively) and of hippocampal [CA3], substantia nigra [SubNigr] and caudate-putamen [C-P] sections of mice with bupropion $\mathrm{HCl}$ - (D, E, F, J, K, L, P, Q, R) and bupropion HBr-induced (G, H, I, M, N, O, S, T, U) seizures 24 hours following the administration of drug (Kainic acid or I25 mg/kg of bupropion salt).A-C: (A) shows NeuN immunostaining of some hippocampal area CA3 neurons particularly in the lower right side of the panel indicating the presence of neurons and the absence of NeuN staining in the upper left part of the panel indicating the loss of NeuN immunoreactivity probably from degradation of NeuN antigen from the degenerative process resulting from kainic acid-induced seizures; (B) a number of TUNEL-positive cells in the upper left part of the panel (arrows) indicating presence of cell death from kainic acidinduced seizures; and (C) Fluoro-Jade B staining of degenerating neurons in hippocampal section stained bright yellow-green (arrows) against a dark background from kainic acid-induced seizures. D-U: NeuN immunostaining of large numbers of cells in sections from the hippocampus (D and G), substantia nigra (J and $M$ ) and caudate-putamen ( $\mathrm{P}$ and S) of mice with bupropion $\mathrm{HCl}$ - and bupropion $\mathrm{HBr}$-induced seizures, respectively, confirming the presence of neurons; note absence of TUNEL-positive cells and hence, any cell death resulting from the administration of bupropion $\mathrm{HCl}$ or bupropion $\mathrm{HBr}$ in the hippocampus ( $\mathrm{E}$ or $\mathrm{H})$, substantia nigra $(K$ or $\mathrm{N})$, and caudate-putamen $(\mathrm{Q}$ or $\mathrm{T})$; and similarly, note absence of Fluoro-Jade B-positive cells indicating the absence of degenerating neurons resulting from the administration of bupropion $\mathrm{HCl}$ or bupropion $\mathrm{HBr}$ in the hippocampus ( $\mathrm{F}$ or I), substantia nigra ( $\mathrm{L}$ or $\mathrm{O})$, and caudate-putamen ( $\mathrm{R}$ or $\mathrm{U})$.

Notes: Bar in A, B, D, E, G, H, J, K, M, N, P, Q, S and T $=45 \mu \mathrm{m}$; and bar in C, F, I, L, O, R, and U = $500 \mu \mathrm{m}$.

Abbreviations: TUNEL, terminal deoxynucleotidyl dUTP nick end labeling; F-JB, Fluoro-Jade B; Bup-HCl, bupropion $\mathrm{HCl}$; Bup-HBr, bupropion $\mathrm{HBr}$. 
from seizure-induced injury. TUNEL and Fluoro-Jade B staining of the section revealed TUNEL-positive (Figure 1-B) and Fluoro-Jade B-positive (Figure 1-C) cells in that location of the section confirming the presence of dead and degenerating neurons, respectively.

\section{EEG trace monitoring in the rat}

\section{Rat EEG findings}

Isolated and infrequent atypical EEG events of probably nonpathologic character were observed on various occasions at all doses. Some events were observed before and after substance administration and do not appear to be directly linked to or predispose to seizure activity. Also, in three rats, short seizure activity was observed in the hippocampus before bupropion $\mathrm{HCl}$ administration (baseline), which may be an indication that those rats were seizure prone. However, all three rats had been administered the test substance $(30,60$, and $100 \mathrm{mg} / \mathrm{kg}$ respectively) the day before.

Following IP administration of test substance, there was no seizure activity observed in either the cortex or hippocampus in any rat administered bupropion $\mathrm{HCl}$ or bupropion $\mathrm{HBr} 10,30$, or $60 \mathrm{mg} / \mathrm{kg}$. However, at $100 \mathrm{mg} / \mathrm{kg}$, seizures were observed following both treatments with the seizures generally starting in the cortex, but of shorter duration in the hippocampus than in the cortex with both salt forms. Seizure onset delay was very short for both salt forms, and was approximately three minutes for the $\mathrm{HCl}$ salt and approximately two minutes for the $\mathrm{HBr}$ salt. In the bupropion $\mathrm{HCl} 100 \mathrm{mg} / \mathrm{kg}$ treatment group and following administration of treatment, all 10 rats had between one to four seizures recorded in both the cortex and hippocampus (Table 2; Figure 2A and B). In both the cortex and hippocampus, of the 10 rats administered bupropion $\mathrm{HCl} 100 \mathrm{mg} / \mathrm{kg}$, one rat had four seizures, four rats had two seizures each (except one that had one seizure only in the cortex), and the remaining five had one seizure each. In contrast, at $100 \mathrm{mg} / \mathrm{kg}$ in the bupropion $\mathrm{HBr}$ treatment group, only four rats had one seizure each in both the cortex and hippocampus (Table 2; Figure 3A and B). Between the two treatments at the $100 \mathrm{mg} / \mathrm{kg}$ dose, there was a significant difference (bupropion $\mathrm{HCl}=10$; bupropion $\mathrm{HBr}=4 ; \mathrm{p}<0.05)$ in the number of rats with seizure activity. All seizures observed following both treatments were long seizure activities (4-60 seconds), with no significant difference in the mean duration of the initial seizure phase in the cortex and hippocampus between the two treatments (Table 2). However, the total duration of all occurrences of seizures were 424.6 and 361.2 seconds in the cortex and hippocampus, respectively, for bupropion $\mathrm{HCl}$ treatment, while it was 124.5 and 90.5 seconds in the cortex and hippocampus, respectively, for bupropion $\mathrm{HBr}$ treatment. This represents a $341 \%$ and $399 \%$ longer total duration of seizures in the cortex and hippocampus, respectively, in the bupropion $\mathrm{HCl}$ treatment group compared to the bupropion $\mathrm{HBr}$ group (Table 2).

\section{Behavioral observations}

Following the administration of bupropion $\mathrm{HBr} 10 \mathrm{mg} / \mathrm{kg}$ and $60 \mathrm{mg} / \mathrm{kg}$ and prior to launching data acquisition, one rat had a short lasting facial clonus and a fatal whole body clonus, respectively, hence were not captured on the EEG. At the $10 \mathrm{mg} / \mathrm{kg}$ dose, no abnormal behavior was observed following the administration of both treatments, while at the 30,60 , and $100 \mathrm{mg} / \mathrm{kg}$ doses, all rats administered either the $\mathrm{HCl}$ salt but not the $\mathrm{HBr}$ salt $(30 \mathrm{mg} / \mathrm{kg}$ ) or both salts showed hyperactivity/stereotypical behavior. In addition, following bupropion $\mathrm{HCl} 100 \mathrm{mg} / \mathrm{kg}$ treatment, all 10 rats (100\%) were observed to have convulsions expressed as facial clonus with or without forelimb clonus and rearing (Table 3 ). In contrast, following

Table 2 Comparative effects of bupropion hydrochloride and bupropion hydrobromide on the EEG trace in rats: long seizure activity (4-60 seconds)

\begin{tabular}{|c|c|c|c|c|c|}
\hline \multirow[t]{2}{*}{$\begin{array}{l}\text { Treatment/number } \\
\text { of animals }\end{array}$} & \multirow{2}{*}{$\begin{array}{l}\text { Number of } \\
\text { animals with } \\
\text { seizure activity }\end{array}$} & \multicolumn{2}{|c|}{$\begin{array}{l}\text { Duration of initial seizure } \\
\text { (seconds) }\end{array}$} & \multicolumn{2}{|c|}{$\begin{array}{l}\text { Total duration of seizures }{ }^{\dagger} \\
\text { (seconds) }\end{array}$} \\
\hline & & $\begin{array}{l}\text { Cortex } \\
(\text { Mean } \pm \text { SEM) }\end{array}$ & $\begin{array}{l}\text { Hippocampus } \\
\text { (Mean } \pm \text { SEM) }\end{array}$ & Cortex & Hippocampus \\
\hline $\begin{array}{l}\text { Bupropion } \mathrm{HCl} \\
100 \mathrm{mg} / \mathrm{kg} \mathrm{IP} \mathrm{n}=10\end{array}$ & 10 & $33 \pm 3$ & $25 \pm 4$ & 424.6 & 361.2 \\
\hline $\begin{array}{l}\text { Bupropion } \mathrm{HBr}^{*} \\
100 \mathrm{mg} / \mathrm{kg} \mathrm{IP} \mathrm{n}=9 \text { ** }\end{array}$ & $4 * * *$ & $31 \pm 6$ & $23 \pm 2$ & 124.5 & 90.5 \\
\hline
\end{tabular}

Notes: ${ }^{\dagger}$ Total duration of seizures was the total duration of all seizures (initial and subsequent episodes) recorded in rats in each treatment group. *Dose of bupropion $\mathrm{HBr}$ is $\mathrm{mg} / \mathrm{kg}$ of bupropion $\mathrm{HCl}$ molar equivalent (correction factor $=1.16$ ). **One rat had a fatal whole body clonus after dosing with bupropion $\mathrm{HBr} 60 \mathrm{mg} / \mathrm{kg} \mathrm{IP}$ prior to launching data acquisition, hence, it was not captured on the EEG. *** $<0.05$ (Chi-square test) compared to the corresponding value for bupropion $\mathrm{HCl}$.

Abbreviations: $\mathrm{EEG}$, electroencephalogram; SEM, standard error of the mean; $\mathrm{HCl}$, hydrochloride; $\mathrm{IP}$, intraperitoneal injection; $\mathrm{HBr}$, hydrobromide. 


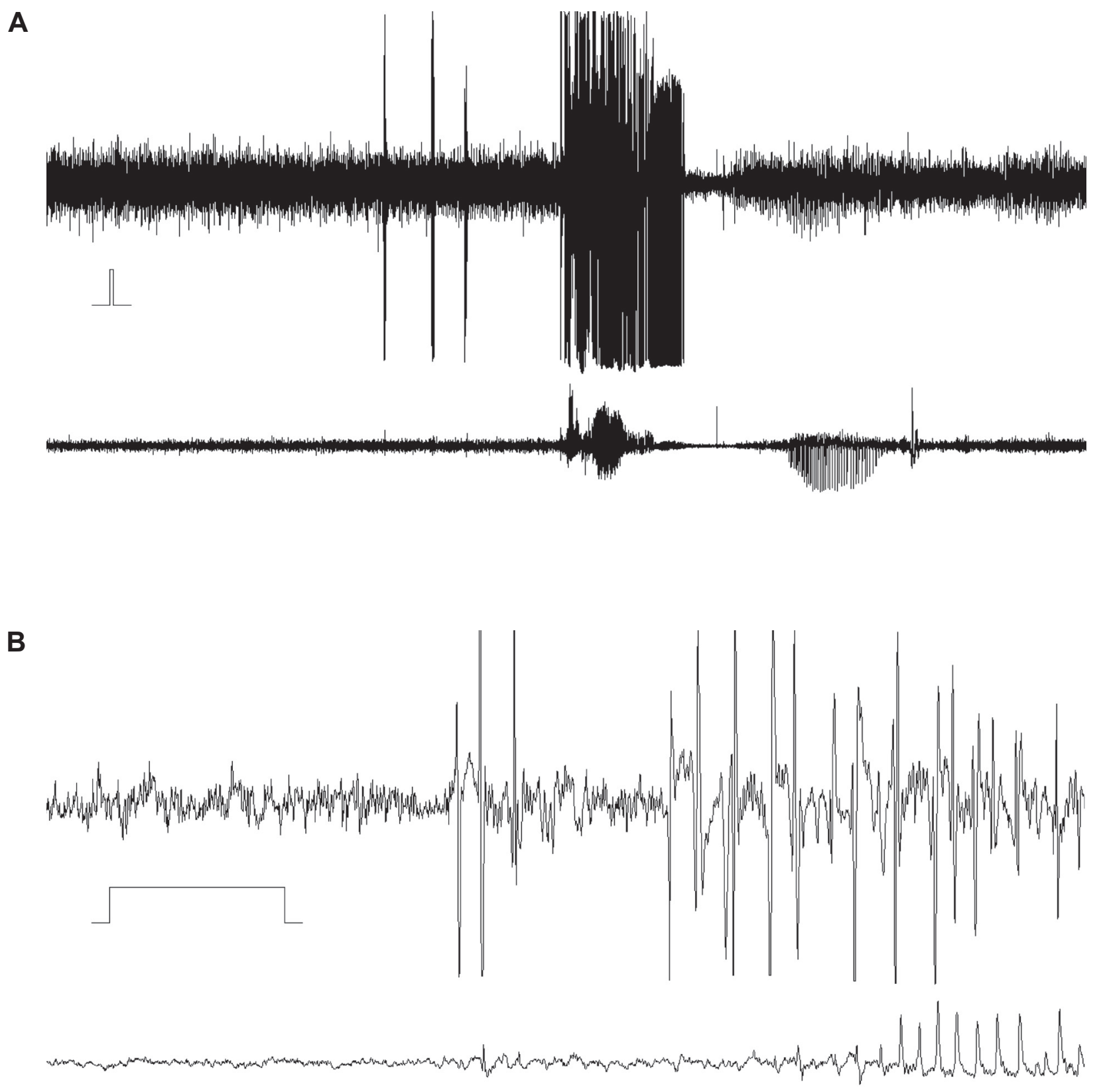

Figure 2 Five minutes of simultaneously recorded cortical (upper trace) and hippocampal (lower trace) EEG following the administration of bupropion hydrochloride $100 \mathrm{mg} / \mathrm{kg}$ intraperitoneally to a rat showing a seizure episode. A) The seizure lasted 35.2 seconds and 30.6 seconds in the cortex and hippocampus, respectively. The time and amplitude calibration bar is indicated between the traces to the left. The initial phase of the seizure activity is shown at higher time resolution. B) Behaviorally, hyperactivity/stereotypical behavior and facial clonus (Racine ${ }^{23}$ Class I) were observed simultaneously in the same rat. EEG = electroencephalogram.

bupropion $\mathrm{HBr} 100 \mathrm{mg} / \mathrm{kg}$ treatment, only five rats $(50 \%)$ were observed to have convulsions that were also expressed as facial clonus with or without forelimb clonus and rearing (except one rat that had a fatal whole body clonus). Between the two treatments at $100 \mathrm{mg} / \mathrm{kg}$, the number of rats with moderate-to-severe convulsions (Racine ${ }^{23}$ Class III to V) were similar for both treatments. However, more rats in the bupropion $\mathrm{HCl}$ treatment group (70\%) had mild convulsions compared to those in the bupropion $\mathrm{HBr}$ treatment group
(20\%) (Table 3). Furthermore, following both treatments, facial clonus was the most consistent behavioral correlate of long EEG seizure activity, both occurring simultaneously in all rats with seizures at the $100 \mathrm{mg} / \mathrm{kg}$ dose.

\section{Assessment of relative convulsant activity in mice}

Since the same doses of bupropion, study design, and strain of mice as in the dosage range-finding study ${ }^{24}$ were used in 


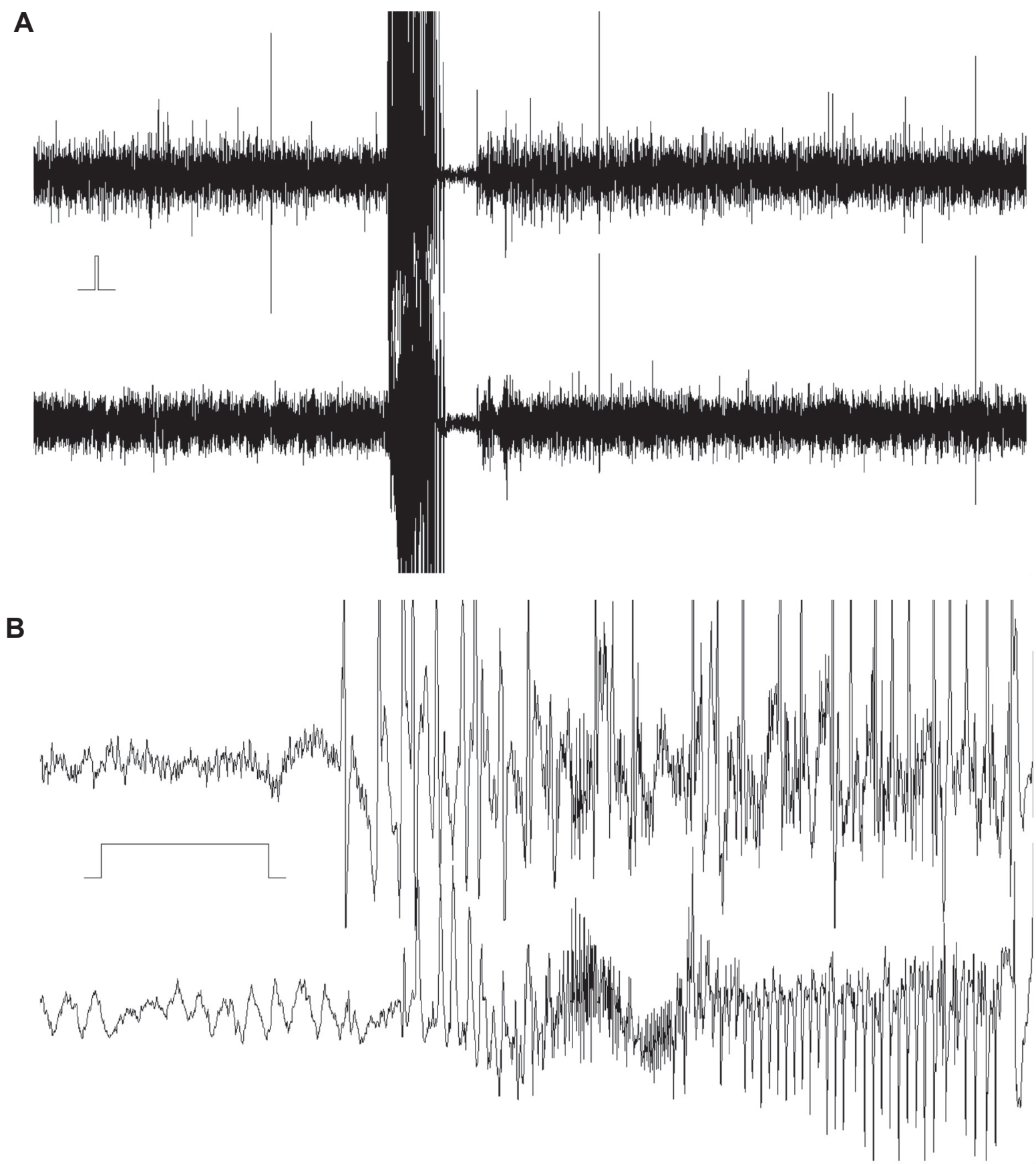

Figure 3 Five minutes of simultaneously recorded cortical (upper trace) and hippocampal (lower trace) electroencephalogram (EEG) following the administration of bupropion hydrobromide $100 \mathrm{mg} / \mathrm{kg}$ intraperitoneally to a rat showing a seizure episode. A) The seizure lasted I6.9 seconds and I6.7 seconds in the cortex and hippocampus, respectively. The time and amplitude calibration bar is indicated between the traces to the left. The initial phase of the seizure activity is shown at higher time resolution. B) Behaviorally, hyperactivity/stereotypical behavior, facial clonus and forelimb clonus (Racine ${ }^{23}$ Class III) were observed simultaneously in the same rat.

this definitive study, the results presented here are the pooled results of the two studies.

\section{Percent (\%) of convulsing mice}

Administration of single doses of both treatments induced convulsions in mice in a dose-dependent manner with the 125 and $150 \mathrm{mg} / \mathrm{kg}$ doses showing the largest effect with bupropion $\mathrm{HCl}$ and the $150 \mathrm{mg} / \mathrm{kg}$ dose with bupropion $\mathrm{HBr}$ (Figure 4). The percent of convulsing mice were $15 \%$, $100 \%$, and $100 \%$ for bupropion $\mathrm{HCl} 100,125$ and $150 \mathrm{mg} / \mathrm{kg}$, respectively, and $23 \%, 85 \%$, and $100 \%$ for bupropion $\mathrm{HBr}$ 100,125 , and $150 \mathrm{mg} / \mathrm{kg}$, respectively. The $\mathrm{CD}_{50}$ or convulsive dose $_{50}$ for bupropion $\mathrm{HCl}$, the convulsive dose of bupropion $\mathrm{HCl}$ required to induce convulsions in $50 \%$ of mice was 
Table 3 Comparative behavioral effects of bupropion hydrochloride and bupropion hydrobromide in rats: severity of observed convulsions

\begin{tabular}{|c|c|c|}
\hline $\begin{array}{l}\text { Class } \\
\text { (Racine 1972)* }\end{array}$ & $\begin{array}{l}\text { Bupropion } \mathrm{HCl} \\
100 \mathrm{mg} / \mathrm{kg} \\
\text { IP }(\mathrm{n}=10)\end{array}$ & $\begin{array}{l}\text { Bupropion } \mathrm{HBr} * * \\
100 \mathrm{mg} / \mathrm{kg} \\
\mathrm{IP} /(\mathbf{n}=10)\end{array}$ \\
\hline I & 7 (70\%) & $2(20 \%)$ \\
\hline II & - & - \\
\hline III & - & I (I0\%) \\
\hline IV & $2(20 \%)$ & I (I0\%) \\
\hline V & I (10\%) & I $(10 \%)^{* * *}$ \\
\hline
\end{tabular}

Notes: *Racine; ${ }^{23}{ }^{*}$ Dose of bupropion $\mathrm{HBr}$ is $\mathrm{mg} / \mathrm{kg}$ of bupropion $\mathrm{HCl}$ molar equivalent (correction factor $=1.16$ ); ***One rat had a fatal whole body clonus after dosing with bupropion $\mathrm{HBr} 60 \mathrm{mg} / \mathrm{kg}$ IP prior to launching data acquisition, hence, it was not captured on the EEG.

Abbreviations: EEG, electroencephalogram; $\mathrm{HCl}$, hydrochloride; IP, intraperitonea injection; $\mathrm{HBr}$, hydrobromide.

$103 \mathrm{mg} / \mathrm{kg}$ (confidence intervals could not be estimated due to lack of data) while the $\mathrm{CD}_{50}$ for bupropion $\mathrm{HBr}$ was 110 (CI: $100.3,117.9) \mathrm{mg} / \mathrm{kg}$. The $\mathrm{CD}_{50}$ values obtained for the two treatments were not statistically significantly different.

\section{Mean convulsions per mouse and intensity of convulsions}

Single-dose bupropion $\mathrm{HCl}$ and bupropion $\mathrm{HBr}$ treatment induced a dose-dependent increase in both the total number of convulsions and the mean convulsions per mouse (Table 4). The mean convulsions per mouse varied from about 0 at the $100 \mathrm{mg} / \mathrm{kg}$ dose to the highest rates at the $150 \mathrm{mg} / \mathrm{kg}$ dose for each treatment. Similarly, the intensity of convulsions (mild, moderate and severe) showed a dose-dependent increase from approximately 0 at the $100 \mathrm{mg} / \mathrm{kg}$ dose to the highest rates at the $150 \mathrm{mg} / \mathrm{kg}$ dose for each treatment (Table 4). However, bupropion $\mathrm{HCl}$ treatment appeared to have proportionately more severe convulsions at every dose level compared to bupropion $\mathrm{HBr}$ treatment. The Cochran-Mantel-Haenszel test performed to detect any general difference in the patterns of convulsion occurrence in terms of intensity (severity) between the two treatments while controlling for dose, showed that the association between treatment $(\mathrm{HCl}$ or $\mathrm{HBr})$ and severity of convulsions, was statistically significant $(\mathrm{p}<0.0001)$. This indicates that, given any dose level, there was statistical evidence that the two treatments had different patterns in terms of convulsion intensities. The latter results confirm the earlier observation of a difference in the proportion of severe convulsions between the two treatments at the different dose levels.

\section{Motor impairment in mice}

In the preliminary determination of the TPE, no notable difference in the TPE between the two salts was noted,

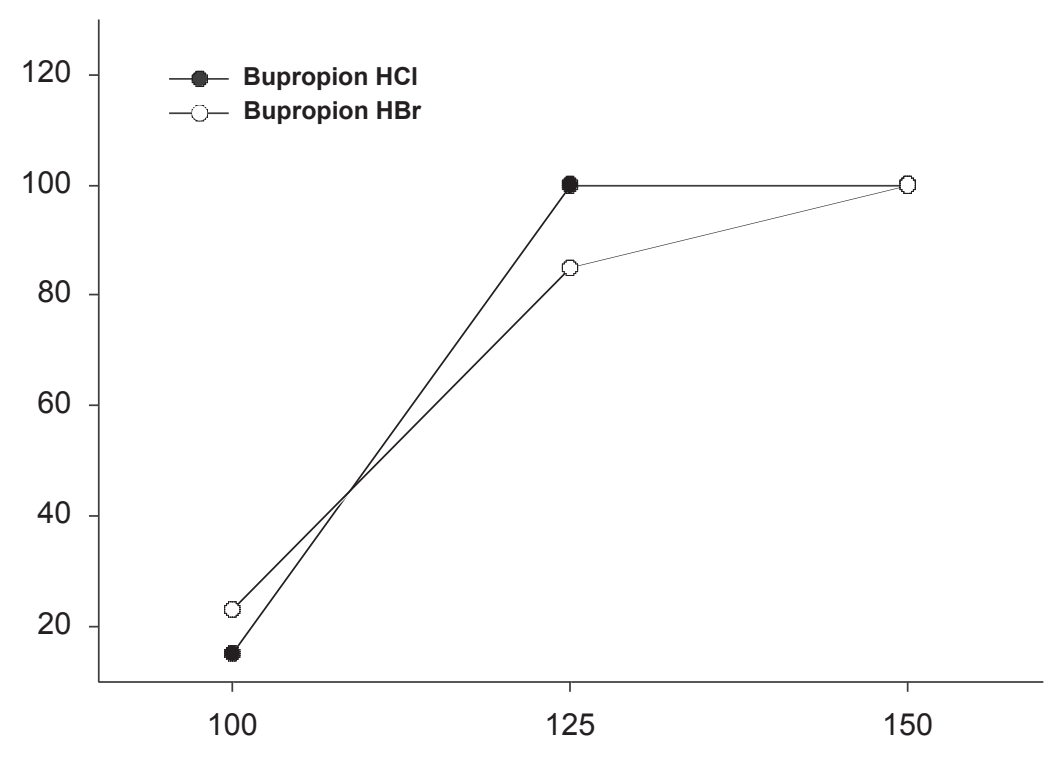

Dose of Bupropion ( $\mathrm{mg} / \mathrm{kg}$ )

Figure 4 Dose-response curves of the percent (\%) of convulsing mice following the intraperitoneal (IP) administration of bupropion $\mathrm{HCl}$ (closed circles) and bupropion $\mathrm{HBr}$ (open circles) in mice. The $\mathrm{CD}_{50}$ or Convulsing Dose ${ }_{50}$ values, the convulsant doses required to induce convulsions in $50 \%$ of mice were 103 (Cl: could not be estimated due to lack of data) and IIO (Cl: I00.3, I79.9) $\mathrm{mg} / \mathrm{kg}$ for the dose-response curves for bupropion $\mathrm{HCl}$ and bupropion $\mathrm{HBr}$, respectively. Doses of bupropion $\mathrm{HCl}$ administered IP were 100,125 , and $150 \mathrm{mg} / \mathrm{kg}$. Bupropion $\mathrm{HBr}$ doses were molar equivalents of the bupropion $\mathrm{HCl}$ doses. Each data point is the \% of convulsing mice in $\mathrm{n}=13$ mice. Abbreviations: $\mathrm{HCl}$, hydrochloride; $\mathrm{HBr}$, hydrobromide. 
Table 4 Total and mean convulsions per mouse by intensity and dose for the bupropion hydrochloride and bupropion hydrobromide treatments

\begin{tabular}{|c|c|c|c|c|}
\hline \multirow{2}{*}{$\begin{array}{l}\text { Dose }(\mathrm{mg} / \mathrm{kg})^{*} \mathrm{n}=13 \text { per } \\
\text { dose per treatment** }\end{array}$} & \multicolumn{2}{|l|}{ Bupropion $\mathrm{HCl}$} & \multicolumn{2}{|l|}{ Bupropion HBr } \\
\hline & $\begin{array}{l}\text { Total number } \\
\text { of convulsions }\end{array}$ & $\begin{array}{l}\text { Mean convulsions } \\
\text { per mouse }^{\dagger}\end{array}$ & $\begin{array}{l}\text { Total number } \\
\text { of convulsions }\end{array}$ & $\begin{array}{l}\text { Mean convulsions } \\
\text { per mouse }{ }^{\dagger}\end{array}$ \\
\hline \multicolumn{5}{|l|}{100} \\
\hline Severe & 2 & 0.15 & 0 & 0.0 \\
\hline Moderate & I & 0.08 & 1 & 0.08 \\
\hline Mild & 0 & 0.0 & 9 & 0.69 \\
\hline \multicolumn{5}{|l|}{125} \\
\hline Severe & 128 & 9.85 & 79 & 6.08 \\
\hline Moderate & 18 & 1.38 & 53 & 4.08 \\
\hline Mild & 32 & 2.46 & 35 & 2.69 \\
\hline \multicolumn{5}{|l|}{150} \\
\hline Severe & 729 & 56.08 & 321 & 24.69 \\
\hline Moderate & 113 & 8.69 & 156 & 12.00 \\
\hline Mild & 81 & 6.23 & 129 & 9.92 \\
\hline
\end{tabular}

Notes: *Dose levels are dose of bupropion $\mathrm{HCl}$ and doses of bupropion $\mathrm{HBr}$ are molar equivalent of bupropion $\mathrm{HCl}$ doses; **n $=13$ mice per dose for bupropion $\mathrm{HCl}$ treatment, and for bupropion $\mathrm{HBr}$ treatment for pooled data from two studies; ${ }^{\dagger}$ Mean convulsions per mouse = the total number of convulsions divided by the number of mice in each dose group ( $\mathrm{n}=13$ per group).

Abbreviations: $\mathrm{HCl}$, hydrochloride; $\mathrm{HBr}$, hydrobromide.

and peak intoxication as estimated by the rotarod test was observed at 15 minutes following IP administration. Therefore, the definitive rotarod test was performed at the TPE. Increasing IP doses of both the $\mathrm{HBr}$ and $\mathrm{HCl}$ salts of bupropion resulted in an impairment of rotarod performance. A time- (data not shown in Table 5) and dose-dependent impairment of rotarod performance was noted following the IP administration of both bupropion salts (Table 5). At the pre-determined TPE of 0.25 hour, the $\mathrm{TD}_{50}$ for the two salts were calculated to be 270.9 and $286.8 \mu \mathrm{mol} / \mathrm{kg}$ (or 74.8 and $91.9 \mathrm{mg} / \mathrm{kg}$, respectively) for bupropion $\mathrm{HCl}$ and bupropion $\mathrm{HBr}$, respectively (Table 5). It is noteworthy that at the doses tested, no clinical seizures were observed in this test. Based on these results, no difference in rotarod performance was detected between the two salts of bupropion.

\section{Discussion}

Although bromides are no longer commonly used for the routine treatment of epilepsy in adults, ${ }^{12,28}$ they still have a role in the treatment of pediatric patients who are refractory to or who cannot tolerate other antiepileptic drugs. ${ }^{12}$ A new salt formulation of bupropion, bupropion $\mathrm{HBr}$, has been developed for the treatment of patients with depression based on a number of factors. However, once developed it is important to determine whether or not the bromide component could potentially reduce the seizure risk associated with the use of bupropion in animals and humans. To test this hypothesis safety pharmacology studies need to be conducted to investigate its proconvulsant liability as well as any potential undesirable pharmacodynamic effects it may have on central nervous system (CNS) physiological functions. ${ }^{29}$ Therefore, the CNS safety pharmacology of bupropion $\mathrm{HBr}$ was assessed by comparing its effects to that of bupropion $\mathrm{HCl}$ on: (i) brain electrical seizure activity by quantified EEG in conscious mice and rats; and (ii) on general behavioral effects including proconvulsant and motor coordination effects in conscious rats and mice. Equimolar but increasing doses of both salts of bupropion were administered IP to mice $(100-150 \mathrm{mg} / \mathrm{kg}$ ) and rats $(10-100 \mathrm{mg} / \mathrm{kg})$ in the EEG trace monitoring studies and to mice in the range $50-150 \mathrm{mg} / \mathrm{kg}$ to assess convulsive liability and motor impairment.

\section{EEG seizures in mice}

The results showed that significant cortical EEG seizure activity was only detected at the $125 \mathrm{mg} / \mathrm{kg}$ dose, and bupropion $\mathrm{HCl}$ administration was associated with a ten-fold higher mean number of EEG seizures in mice that was statistically significant compared to equimolar bupropion $\mathrm{HBr}$ even though no EEG seizure activity was detected in the fourth pair of mice dosed with either salt at this dose. Furthermore, the mean duration of seizures at the $125 \mathrm{mg} / \mathrm{kg}$ dose showed a strong trend to overall increased 
Table 5 Dose-dependent motor impairment of bupropion hydrochloride and bupropion hydrobromide in the rotarod test in mice

\begin{tabular}{|c|c|c|c|c|}
\hline $\begin{array}{l}\text { Test } \\
\text { compound }\end{array}$ & $\begin{array}{l}\text { Time of test } \\
\text { (hour) }\end{array}$ & $\begin{array}{l}\text { Dose } \\
(\mathrm{mg} / \mathrm{kg} \text { IP) }\end{array}$ & $\begin{array}{l}\text { Number toxicl } \\
\text { Number tested* }\end{array}$ & $\begin{array}{l}\operatorname{TD}_{50}(95 \% \text { confidence } \\
\text { interval) }\end{array}$ \\
\hline \multirow[t]{5}{*}{ Bupropion $\mathrm{HCl}$} & 0.25 & 50 & $0 / 8$ & 74.8 mg/kg \\
\hline & & 60 & $1 / 8$ & (65.9-87.7) \\
\hline & & 75 & $5 / 8$ & or \\
\hline & & 100 & $7 / 8$ & $270.9 \mu \mathrm{mol} / \mathrm{kg}$ \\
\hline & & & & $(238.6-317.4)$ \\
\hline \multirow[t]{5}{*}{ Bupropion $\mathrm{HBr} * *$} & 0.25 & 75 & $0 / 8$ & $91.9 \mathrm{mg} / \mathrm{kg}$ \\
\hline & & 85 & $4 / 8$ & (83.5-III.I) \\
\hline & & 100 & $5 / 8$ & or \\
\hline & & 150 & $8 / 8$ & $286.8 \mu \mathrm{mol} / \mathrm{kg}$ \\
\hline & & & & $(260.3-346.3)$ \\
\hline
\end{tabular}

Notes: *Results are expressed as number of mice failing rotarod test over number of mice tested at each dose tested; **Doses of bupropion $\mathrm{HBr}$ are $\mathrm{mg} / \mathrm{kg}$ of bupropion $\mathrm{HCl}$ molar equivalent.

Abbreviations: IP, intraperitoneal injection; $\mathrm{TD}_{50}$, toxic dose ${ }_{50}$ ie, the molar dose of each salt required to produce rotarod impairment in $50 \%$ of animals; $\mathrm{HCl}$, hydrochloride; $\mathrm{HBr}$, hydrobromide.

seizure duration in the $\mathrm{HCl}$ group where the mean duration was ten-fold higher in mice administered bupropion $\mathrm{HCl}$ compared to equimolar bupropion $\mathrm{HBr}$. The reason for the variable effect of the salts on the EEG at the $125 \mathrm{mg} / \mathrm{kg}$ dose observed in this study is not clear but it could be due to one or more number of factors, including simple and inherent in vivo biological variability, a CD-1 mouse-specific genotype effect, the use of female mice with the possible introduction of oestrous cycle events, and a higher than previous mouse study weight. The CD-1 mice used in the study were $25 \mathrm{~g}$ and higher in weight, which may be higher than was previously used for behavioral testing.

A surprising finding in this study was, at the $150 \mathrm{mg} /$ $\mathrm{kg}$ dose, very brief (2-3 seconds duration) cortical EEG activity was picked up that occurred equally following the administration of either salt of bupropion, with no further seizure activity detected thereafter despite the observed profound convulsive behavior. In addition, no EEG seizure activity was detected following dosing of mice with either salt of bupropion at the 100, 115, and $135 \mathrm{mg} / \mathrm{kg}$ doses. This was surprising because in previous studies with bupropion $\mathrm{HCl}$ in mice, a dose-dependent increase in behavioral seizure activity was demonstrated in the dosage range 75 to $160 \mathrm{mg} / \mathrm{kg}^{7}{ }^{7,830}$ The reason for not detecting any EEG seizure activity even though profound behavioral convulsions were observed following the administration of $150 \mathrm{mg} / \mathrm{kg}$ of either salt, and at the 100 , 115 , and $135 \mathrm{mg} / \mathrm{kg}$ doses is not known. However, it may reside with subcortical pathway activation and inhibition and hence, future studies employing simultaneous cortical and depth electrode recordings may yield the explanations for the lack of EEG recordings with the cortical electrodes used in this study.

\section{Histopathology findings in mice}

An accumulated body of evidence shows that seizures induce a mixed pattern of cell death that includes features consistent with both apoptosis and necrosis, ${ }^{31-36}$ and more recently, that a significant component of seizure-induced neuronal loss may be the result of programmed cell death pathways. ${ }^{37-41}$ The histopathology study results showed the absence of TUNEL-positive cells and Fluoro-Jade B-positive neurons in the stained brain sections of mice indicating that no cell death or neuronal degeneration, respectively, occurred in mice killed 24 hours after seizures induced by the administration of $125 \mathrm{mg} / \mathrm{kg}$ IP of bupropion $\mathrm{HCl}$ or bupropion $\mathrm{HBr}$. The latter complementary results taken together confirmed that that neither the behavioral convulsions, nor the associated electrographic expression, induced by $125 \mathrm{mg} / \mathrm{kg}$ bupropion $\mathrm{HCl}(115-290 \mathrm{sec})$ and bupropion $\mathrm{HBr}(25-30 \mathrm{sec})$ in mice lead to cell death and/or neuronal degeneration as assessed by the highly sensitive in situ DNA fragmentation analysis (TUNEL) ${ }^{14,15}$ or the high affinity fluorescent marker (FluoroJade B), ${ }^{16,18}$ respectively. Furthermore, immunostaining for the neuron-specific antigen, NeuN, ${ }^{19}$ confirmed that the morphology of neurons within hippocampus, striatum and substantia nigra were normal in mice treated with either bupropion salt. This finding of the absence of any histopathological injury following bupropion-induced seizures by either salt is significant because more recently evidence has emerged that brief single and intermittent epileptic seizures can lead to neuronal death. ${ }^{34,39}$ Previously, 
epileptic brain injury had only been demonstrated after continuous and prolonged seizure activity or after a large number of severe intermittent seizures. ${ }^{31-33}$ Thus, while high dose bupropion may cause seizures, these animal data do not support their causing permanent neuronal loss in mouse brain.

\section{EEG trace monitoring in rats}

The results of this sub-study revealed that following the IP administration of both salts of bupropion at $100 \mathrm{mg} / \mathrm{kg}$, bupropion $\mathrm{HBr}$ induced only single EEG seizure activity in the cortex and hippocampus, and in significantly $(\mathrm{p}<0.05)$ fewer rats $(44 \%)$ compared to bupropion $\mathrm{HCl}$ that induced one to four convulsions per rat and in all the rats dosed (100\%). The absence of EEG seizure activity at the 10,30 , and $60 \mathrm{mg} / \mathrm{kg}$ doses in this rat model is consistent with a previous report that bupropion $\mathrm{HCl}$ $5-50 \mathrm{mg} / \mathrm{kg}$ IP did not produce any behavioral convulsions in mice $^{7}$ and with reports of bupropion-induced behavioral convulsions in mice in the dosage range $75-160 \mathrm{mg} / \mathrm{kg}$ IP. ${ }^{7,8,30}$ Although there was no significant difference in the mean duration of the first seizure between the two treatments in the cortex and hippocampus, the total duration of the multiple seizures following bupropion $\mathrm{HCl}$ treatment $100 \mathrm{mg} / \mathrm{kg}$ were $341 \%$ and $399 \%$ longer in the cortex and hippocampus, respectively, compared to equimolar bupropion $\mathrm{HBr}$ treatment. In addition, all EEG seizure activity observed with both treatments were accompanied by simultaneous predominantly mild (facial clonus with or without forelimb clonus and rearing) behavioral convuslions, however, more rats in the bupropion $\mathrm{HCl}$ treatment group $(70 \%)$ had mild convulsions (Racine ${ }^{23}$ Class I - facial clonus) compared to the bupropion $\mathrm{HBr}$ treatment group (20\%). Furthermore, facial clonus was the most consistent observed behavioral correlate of the long EEG seizure activity that was recorded following treatment in all rats with seizures at the $100 \mathrm{mg} / \mathrm{kg}$ dose with both treatments. All these results indicate that bupropion $\mathrm{HBr}$ has a lower potency to induce convulsions compared to equimolar doses of bupropion $\mathrm{HCl}$ in normal conscious rats.

The short seizure activities observed in the hippocampus in three rats are most likely incidental findings, since they occurred in an apparent random fashion. The reason(s) for the unexpected immediate reaction observed in one rat administered $10 \mathrm{mg} / \mathrm{kg}$ and another rat administered $60 \mathrm{mg} /$ $\mathrm{kg}$ bupropion $\mathrm{HBr}$ are not known but may indicate the need for further testing.

\section{Behavioral proconvulsant activity in mice}

The pooled data from the two studies in mice demonstrated that the administration of single doses of both treatments induced convulsions in mice in a dose-dependent manner. The $\mathrm{CD}_{50}$, the convulsive dose required to induce convulsions in $50 \%$ of mice for bupropion $\mathrm{HCl}$ was $103 \mathrm{mg} / \mathrm{kg}$ (confidence intervals could not be estimated due to lack of data) while the corresponding value for bupropion $\mathrm{HBr}$ was 110 (CI: 100.3, 117.9) mg/kg. There was no significant difference between the $\mathrm{CD}_{50}$ values obtained for the two treatments. The demonstration of dose-dependent convulsions in the dosage range $100-150 \mathrm{mg} / \mathrm{kg}$ in this study is consistent with the results of previous studies in mice. . $^{7,30}$ In addition, the $\mathrm{CD}_{50}$ values of 103 and $110 \mathrm{mg} / \mathrm{kg}$ obtained in this study for bupropion $\mathrm{HCl}$ and bupropion $\mathrm{HBr}$ treatments, respectively, are similar to the values of 116.72 (CI: 107.95, 126.20) and 119.7 (CI: 104.1, 137.6) mg/kg reported previously for IP bupropion $\mathrm{HCl}$ administration in mice. ${ }^{7,30}$

Also, single-dose bupropion $\mathrm{HCl}$ and bupropion $\mathrm{HBr}$ treatments induced a dose-dependent increase in the total number of convulsions, the mean convulsions per mouse, and in the intensity of convulsions (mild, moderate, and severe). The values observed for each parameter ranged from approximately 0 at the $100 \mathrm{mg} / \mathrm{kg}$ dose to the highest rates at the $150 \mathrm{mg} / \mathrm{kg}$ dose for each treatment. However, bupropion $\mathrm{HCl}$ treatment had proportionately more severe convulsions at every dose level compared to the bupropion $\mathrm{HBr}$ treatment. The Cochran-Mantel-Haenszel test while controlling for dose, showed that the association between treatment (bupropion $\mathrm{HCl}$ or bupropion $\mathrm{HBr}$ ) and severity of convulsions was statistically significant ( $p<0.0001)$, indicating that given any dose level, there was statistical evidence that the two treatments had different patterns in terms of convulsion intensities. These latter results support the earlier observation of a difference in the proportion of severe convulsions between the two treatments at the different dose levels.

\section{Motor impairment in mice}

A time- and dose-dependent impairment of rotarod performance in mice was noted following the IP administration of both bupropion salts in the dosage range studied. The $\mathrm{TD}_{50}$ for the two salts were similar and were 270.9 and $286.8 \mu \mathrm{mol} /$ $\mathrm{kg}$ (or 74.8 and $91.9 \mathrm{mg} / \mathrm{kg}$, respectively) for bupropion $\mathrm{HCl}$ and bupropion $\mathrm{HBr}$, respectively. Although a time- and dose-dependent impairment of rotarod performance was observed with both bupropion salts, no difference in rotarod 
performance was detected between the two salts. Thus, the results of this study suggest that there is no difference between the effects of bupropion $\mathrm{HCl}$ and bupropion $\mathrm{HBr}$ to decrease neuromuscular coordination.

It is also important to note that the doses given to rodents were those that caused rotarod impairment. These are much higher than those given to patients (3-6 mg/kg/day). However, given the incidence of seizures in humans at these doses $(0.1 \%-0.4 \%)$ it would be impractical to carry out animal studies at these dose ranges.

\section{Conclusion}

The results of these comparative safety pharmacology studies have demonstrated that following IP administration in mice, cortical EEG seizures were only detected at the $125 \mathrm{mg} / \mathrm{kg}$ dose and bupropion $\mathrm{HCl}$ induced a ten-fold higher mean number of seizures that was statistically significant compared to equimolar bupropion $\mathrm{HBr}$. The EEG seizures induced by either salt of bupropion were not associated with any histopathological injury. In addition, in rats bupropion $\mathrm{HBr} 100 \mathrm{mg} / \mathrm{kg}$ induced only single cortical and hippocampal EEG seizure activity and in significantly fewer animals (44\%) compared to equimolar bupropion $\mathrm{HCl}$ that induced 1 to 4 convulsions per animal and in all rats dosed $(100 \%)$. The total duration of the multiple seizures induced by bupropion $\mathrm{HCl} 100 \mathrm{mg} / \mathrm{kg}$ treatment were $341 \%$ and $399 \%$ longer in the cortex and hippocampus, respectively, compared to that induced by equimolar bupropion $\mathrm{HBr}$ treatment. All EEG seizure activity induced by both treatments were accompanied by simultaneous predominantly mild (facial clonus with or without forelimb clonus and rearing) behavioral seizures, however, more rats in the bupropion $\mathrm{HCl}$ treatment group (70\%) had mild behavioral convulsions compared to the bupropion $\mathrm{HBr}$ treatment group (20\%). Facial clonus was a consistent correlate of long EEG seizure activity. Both treatments induced behavioral convulsions in mice in a dose-dependent manner. There was no significant difference in the $\mathrm{CD}_{50}$ values of the dose-response curves obtained for the two treatments. However, bupropion $\mathrm{HCl}$ consistently induced more severe convulsions at each dose level compared to bupropion HBr. Both treatments demonstrated a similar dose-dependent impairment of rotarod performance in mice. In summary, these results indicate that bupropion $\mathrm{HBr}$ appears to have a lower potency to induce EEG seizures in mice and rats, and less severe behavioral convulsions in mice compared to bupropion $\mathrm{HCl}$. These interesting findings merit further investigation in clinical safety studies.

\section{Acknowledgments}

Funding for the conduct of this study was provided by Biovail Laboratories International SRL.

\section{References}

1. GlaxoSmithKline. Wellbutrin ${ }^{\circledR}$ (bupropion hydrochloride) tablets product monograph, July 2006.

2. Peck AW, Stern WC, Watkinson C. Incidence of seizures during treatment with tricyclic antidepressant drugs and bupropion. J Clin Psychiatry. 1983;44:197-201.

3. Van Wyck Fleet J, Manberg PJ, Miller LL, et al. Overview of clinically significant adverse reactions to bupropion. J Clin Psychiatry. 1983;44:191-196.

4. Davidson J. Seizures and bupropion: a review. J Clin Psychiatry. 1989;50:256-261.

5. Johnston JA, Lineberry CG, Ascher JA, et al. A 102-center prospective study of seizure in association with bupropion. J Clin Psychiatry. 1991;52:450-456.

6. Dunner DL, Zisook S, Billow AA, Batey SR, Johnston JA, Ascher JA A prospective safety surveillance study for bupropion sustained-release in the treatment of depression. J Clin Psychiatry. 1998;59:366-373.

7. Tutka P, Barczynski B, Wielosz M. Convulsant and anticonvulsant effects of bupropion in mice. Eur J Pharmacol. 2004;499:117-120.

8. Tutka P, Mroz T, Klucha K, Piekarczyk M, Wielosz M. Bupropioninduced convulsions: preclinical evaluation of antiepileptic drugs. Epilepsy Res. 2005;64:13-22.

9. Data on file. Biovail Study No. B06-802PK-10121. A two-way, crossover, fasting, steady-state dosage strength proportionality study of bupropion hydrobromide XL tablets $(522 \mathrm{mg}$ vs $3 \times 174 \mathrm{mg})$ in normal healthy non-smoking adult volunteers. Chantilly, VA: Biovail Technologies, Ltd.; 2007.

10. Meeting of the Royal Medical and Chirurgical society of London, May 11, 1857. Lancet. 1857;1:527-528.

11. Friedlander WJ. The rise and fall of bromide therapy in epilepsy. Arch Neurol. 2000;57:1782-1785.

12. Ryan M, Baumann RJ. Use and monitoring of bromides in epilepsy treatment. Pediatr Neurol. 1999;21:523-528.

13. Araki T, Simon RP, Taki W, Lan JQ, Henshall DC. Characterization of neuronal death induced by focally evoked limbic seizures in the C57BL/6 mouse. J Neurosci Res. 2002;69:614-621.

14. Gavrieli Y, Sherman Y, Ben-Sasson SA. Identification of programmed cell death in situ via specific labeling of nuclear DNA fragmentation. J Cell Biol. 1992;119:493-501.

15. Lucassen PJ, Chung WC, Vermeulen JP, Van Lookeren Campagne M, Van Dierendonck JH, Swaab DF. Microwave-enhanced in situ endlabeling of fragmented DNA: parametric studies in relation to postmortem delay and fixation of rat and human brain. J Histochem Cytochem. 1995;43:1163-1171.

16. Schmued LC, Albertson C, Slikker W Jr. Fluoro-Jade: a novel fluorochrome for the sensitive and reliable histochemical localization of neuronal degeneration. Brain Res. 1997;751:37-46.

17. Schmued LC, Hopkins KJ. Fluoro-Jade: novel fluorochromes for detecting toxicant-induced neuronal degeneration. Toxicol Pathol. 2000;28:91-99.

18. Schmued LC, Hopkins KJ. Fluoro-Jade B: a high affinity fluorescent marker for the localization of neuronal degeneration. Brain Res. 2000;874:123-130.

19. Mullen RJ, Buck CR, Smith AM. NeuN, a neuronal specific nuclear protein in vertebrates. Development. 1992;116:201-211.

20. Murphy B, Dunleavy M, Shinoda S, et al. Bcl-w protects hippocampus during experimental status epilepticus. Am J Pathol. 2007;171: 1258-1268.

21. Hatazaki S, Bellver-Estelles C, Jimenez-Mateos EM, et al. Microarray profile of seizure damage-refractory hippocampal CA3 in a mouse model of epileptic preconditioning. Neuroscience. 2007;150:467-477. 
22. Dürmüller N, Scherschlicht R, Porsolt RD. Vigilance-controlled quantified EEG in safety pharmacology. Current Protocols in Pharmacology Unit. 2000;10.6.

23. Racine RJ. Modification of seizure activity by electrical stimulation. II. Motor seizure. Electroencephalogr Clin Neurophysiol. 1972;32: 281-294.

24. Paxinos G, Watson C, editors. The Rat Brain in Stereotaxic Coordinates. 5th Edition. Burlington, MA: Elsevier Academic Press; 2005.

25. Dunham MS, Miya TA. A note on a simple apparatus for detecting neurological deficit in rats and mice. J Am Pharm Assoc Am Pharm Assoc (Baltim). 1957;46:208-209.

26. Litchfield JT Jr, Wilcoxon F. A simplified method of evaluating dose-effect experiments. J Pharmacol Exp Ther. 1949;96:99-113.

27. Finney DJ. Probit Analysis. 3rd Edition, London: Cambridge University Press; 1971.

28. Pozuelo-Utanda J, Crawford DC, Anderson JC. Bromism and epilepsy. Int J Neuropsychiatry. 1966;2:90-97.

29. Guidance for industry: ICH S7A Safety pharmacology studies for human pharmaceuticals (FDA, 2001).

30. Silverstone P, Williams R, McMahon L, Fleming R, Fogarty S. Alcohol significantly lowers the seizure threshold in mice when co-administered with bupropion hydrochloride. Ann Gen Psychiatry. 2008;7:11.

31. Pollard H, Cantagrel S, Charriaut-Marlangue C, Moreau J, Ben Ari Y. Apoptosis associated DNA fragmentation in epileptic brain damage. Neuroreport. 1994;5:1053-1055.

32. Pollard H, Charriaut-Marlangue C, Cantagrel S, Represa A, Robain O, Moreau J, Ben-Ari Y. Kainate-induced apoptotic cell death in hippocampal neurons. Neuroscience. 1994;63:7-18.

33. Sloviter RS, Dean E, Sollas AL, Goodman JH. Apoptosis and necrosis induced in different hippocampal neuron populations by repetitive perforant path stimulation in the rat. J Comp Neurol. 1996;366:516-533.
34. Bengzon J, Kokaia Z, Elmér E, Nanobashvili A, Kokaia M, Lindvall O. Apoptosis and proliferation of dentate gyrus neurons after single and intermittent limbic seizures. Proc Natl Acad Sci U S A. 1997;94: 10432-10437.

35. Fujikawa DG, Shinmei SS, Cai B. Seizure-induced neuronal necrosis: implications for programmed cell death mechanisms. Epilepsia. 2000;41(Suppl 6):S9-S13.

36. Fujikawa DG, Shinmei SS, Cai B. Kainic acid-induced seizures produce necrotic, not apoptotic, neurons with internucleosomal DNA cleavage: implications for programmed cell death mechanisms. Neuroscience. 2000;98:41-53.

37. Henshall DC, Bonislawski DP, Skradski SL, Lan JQ, Meller R, Simon RP. Cleavage of bid may amplify caspase-8-induced neuronal death following focally evoked limbic seizures. Neurobiol Dis. 2001;8:568-580.

38. Henshall DC, Araki T, Schindler CK, et al. Activation of Bcl-2-associated death protein and counter-response of Akt within cell populations during seizure-induced neuronal death. J Neurosci. 2002;22: 8458-8465.

39. Bengzon J, Mohapel P, Ekdahl CT, Lindvall O. Neuronal apoptosis after brief and prolonged seizures. Prog Brain Res. 2002;135:111-119.

40. Liou AK, Clark RS, Henshall DC, Yin XM, Chen J. To die or not to die for neurons in ischemia, traumatic brain injury and epilepsy: a review on the stress-activated signaling pathways and apoptotic pathways. Prog Neurobiol. 2003;69:103-142.

41. Shinoda S, Schindler CK, Meller R, et al. Bim regulation may determine hippocampal vulnerability after injurious seizures and in temporal lobe epilepsy. J Clin Invest. 2004;113:1059-1068. 